\title{
Addition of Habenaria pantlingiana Kraenzl. in the Orchid Flora of Nagaland, India.
}

Wenyitso Kapfo ${ }^{1}$ and Neizo Puro ${ }^{2}$

Department of Botany, Nagaland University, Lumami- 798627, Nagaland, India.

Received: 2/5/2018; Received: 2/19/2018; Accepted: 2/24/2018

Abstract: Habenaria pantlingiana Kraenzl. is being reported as a new addition to the Orchid Flora of Nagaland in this communication. Description, range of distribution, photographs and phenology are furnished.

Key words: Habenaria pantlingiana Kraenzl., new record, Orchid Flora, Nagaland.

\section{Introduction}

During floristic explorations of two reserve forests in Kohima district of Nagaland, the first author came across an interesting orchid amongst the ground vegetation of thick-canopied forests on two different occasions viz. August, 2015 and September, 2016. The two protected areas are namely, Jotsoma Community Forest (JCF) and Pulie Badze wildlife Sanctuary (PBWS) which are physically contiguous but separated by barbed wire fencing. Located between $25^{\circ} 35$. $800^{\prime}$ to $25^{\circ}$ $40.100^{\prime} \mathrm{N}$ latitudes and $94^{\circ} 01.700^{\prime}$ to $90^{\circ} 05$. $800^{\prime} \mathrm{E}$ longitudes, they comprise a total area of about $50 \mathrm{sq}$ $\mathrm{km}$.

Only two individuals were encountered, one at JCF (N25 39.128 E94 04.210) and the other at PBWS (N25 38.931 E94 05.106) at the elevation of $1931 \mathrm{~m}$ amsl and $1766 \mathrm{~m}$ amsl respectively. On close examination of the specimens, it was concluded that both specimens belong to Habenaria pantlingiana Kraenzl., a new record for Nagaland.

\section{Materials and Methods}

Seasonal field explorations were conducted from 2015 to 2016 for observation and collection of the plant specimen. Fresh specimens were collected, processed and mounted on herbarium sheets after the standard method as given by Jain \& Rao (1977). Authentic identification was done with the help of literature and comparison with specimens at ASSAM herbarium. A herbarium specimen has been deposited at the herbarium, Department of Botany, Nagaland University, Lumami, Nagaland, India.

\section{Results}

This specimen fits the overall description given for the plant occurring in China (Chen et al., 2009), Sikkim (King \& Pantling 1898), Bhutan (Pearce \& Crib 2002), Arunachal Pradesh (Chowdhery 1998) and Thailand (Kurzweil 2009). However, this plant was seen amongst ground vegetation under thick canopied forest and not in open spaces as described in most other reports. The plant is described in the following:

Habenaria pantlingiana Kraenzl. Orchid. Gen. Sp. 1: 892. 1900; Habenaria cirrbifera Ohwi, Acta Phytotax. Geobot. 1: 141 1932; Habenaria longitentaculata Hayata, Ion. Pl. Formosan. 4: 127 1914; Habenaria stenopetala var. polytricha Hook.f. , Ann. Roy. Bot. Gard. (Calcutta) 5: 64 1895; Habenaria seshagiriana A.N.Rao, J. Econ. Taxon. Bot. 6: 2231985.

Terrestrial herb, plants about $70 \mathrm{~cm}$ tall. Tubers fleshy, oblong, ca. $2-4 \times 1-2.5 \mathrm{~cm}$. Stem erect, green, cylindrical, stout, 6 to 8 leaves spirally arranged near middle of the stem and $2-5$ bract-like leaves above it. Leaf lamina oblong-lanceolate or obovate-lanceolate, $10-15 \times 3.0-4.5 \mathrm{~cm}$, base attenuate, narrowed into amplexicaul sheath, margin undulate, apex acute or acuminate, slightly curved. Inflorescence, up to $4-12.5 \mathrm{~cm}$ long, densely many flowered raceme, floral bracts persistent, lanceolate, $16-24 \times 2.5-4.2 \mathrm{~mm}$, usually longer than or as long as ovary, apex long acuminate. Flowers green, dorsal sepal prominently erect, lanceolate, concave, apex long acuminate and caudate, 2.0-3.0 $\times$ 0.4-0.6 $\mathrm{cm}$, lateral sepals reflexed, oblique, linear, 1.8-2.5 $\times$ $0.3-0.5 \mathrm{~cm}$, apex long acuminate and caudate, petals deeply bi-lobed from base, divergent, lobes filiform, upper lobe 1.1-1.5 x ca. $0.3 \mathrm{~cm}$, lower lobe 1.8-2.0x ca. $0.3 \mathrm{~cm}$, filiform, tortuous, lip tri-lobed from base, $2.0-2.5 \mathrm{~cm} \times$ ca. $0.7 \mathrm{~mm}$, lobes filiform, tortuous, mid-lobe usually shorter than lateral lobes, spur pendulous, cylindrical, $1.5-2.0 \mathrm{~cm}$ long, as long as ovary, ovary cylindrical, twisted, $1.7-2.2 \mathrm{~cm}$ long, glabrous; pollinia oblong, viscidia, small, orbicular, stigmas club shaped.

\footnotetext{
${ }^{*}$ Corresponding Author:

Wenyitso Kapfo,

Department of Botany, Nagaland University,

Lumami- 798627, Nagaland, India.

E-mail:wenitso@gmail.com
}

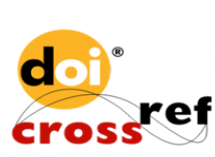



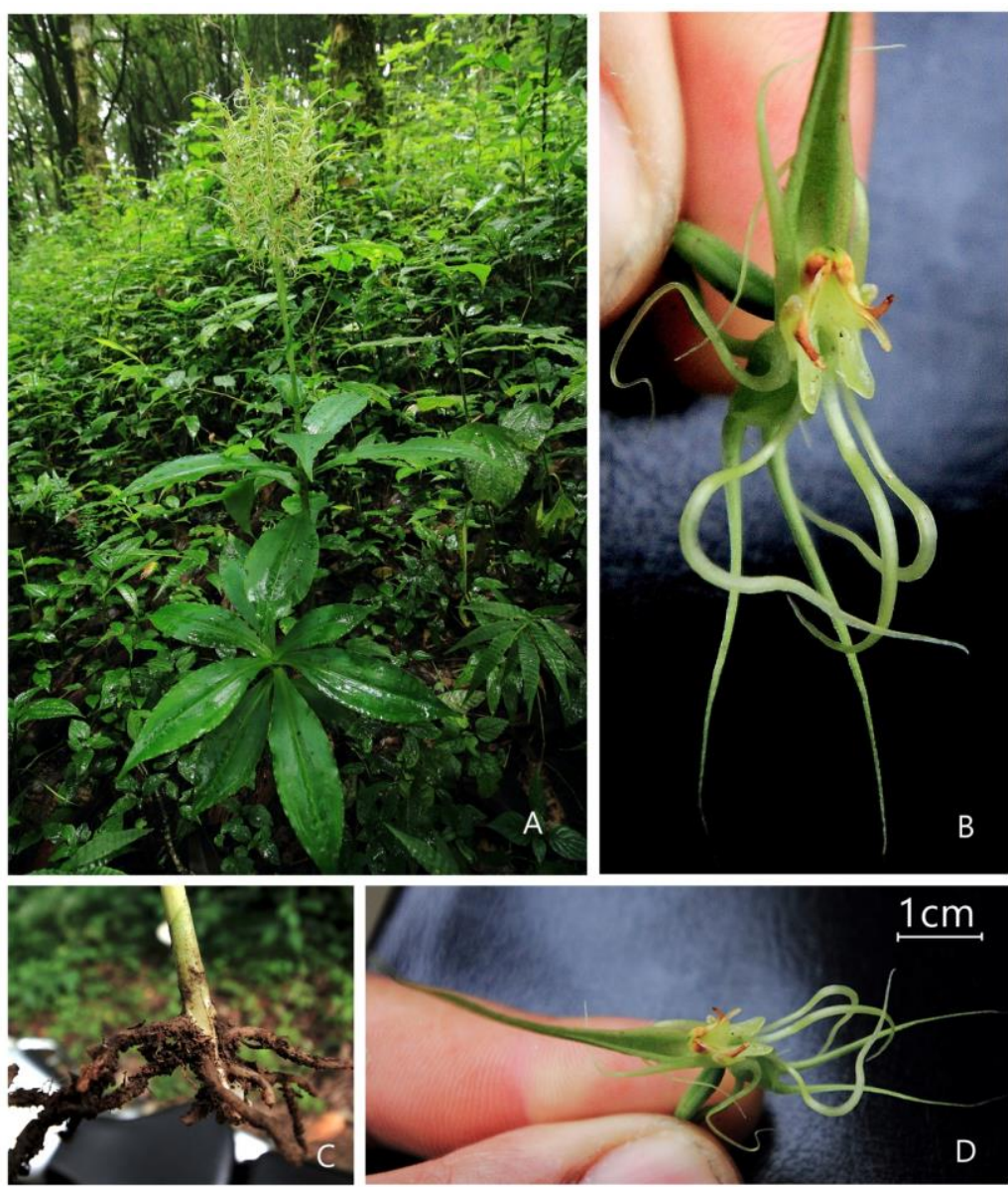

Figure A: Habit and habitat; B: Close-up view of flower; C: Roots (without pseudobulb) D: Full view of flower

Distribution: China (SW Guangxi, SE Hainan), N. Taiwan, India (N.Bengal, Sikkim and Arunachal Pradesh), Bhutan, Thailand, Japan (Ryukyu Islands), Nepal and Vietnam.

Flowering: August to October

Ecology / Habitat. It grows amongst ground vegetation under thick canopy of sub-tropical oak forest as well as sub-tropical mixed-evergreen forest showing low frequency and low density.

Specimen examined: Jotsoma Community Forest (N25 39.128 E94 04.210) at 1931m and Pulie Badze wildlife Sanctuary (N25 38.931 E94 05.106) at $1766 \mathrm{~m}$.

Exsiccatae: NUK-063 (Nagaland University), dated 05.09.2015

\section{Discussion and Conclusion}

Interestingly, a similar specimen had been collected by Prain in 1895 from broadly the same area but it was identified as Habenaria stenopetala var. polytricha Hook.f. The authors could not confirm whether or not this old specimen is identical to the present collection. In any case, Habenaria pantlingiana Kraenzl. has not yet been reported from Nagaland (Changkija et al., 1992, Deorani \& Naithani1995,
Hynniewta et al., 2000, Deb et al., 2003, Deb \& Imchen 2008, Chowdhery 2009, Choudhury et al., 2011). Hence, this communication reports that Habenaria pantlingiana Kraenzl. is a new addition to the orchid flora of Nagaland.

\section{Acknowledgement}

The authors are thankful to the government of Nagaland for facilitating this work by way of granting study leave (to the first author), faculty of Department of Botany, Nagaland University for encouragement, and also to research colleagues, Mr. Santanu Dey in particular, for cheerful support in terms of valuable suggestions and generous sharing of knowledge resources.

\section{References}

1. Changkija S, Y Kumar and P B Gurung. "Orchids of Nagaland". Forest department of Nagaland, India, 1995.

2. Chen $X, Z$ Liu, G Zhu, K Lang, Z Ji, Z Luo, $X$ Jin, P J Cribb, J J Wood, S W Gale, P Ormerod, J J Vermeulen, HP Wood, D Clayton and A Bell. "Orchidaceae". In: Wu Z, PH Raven \& D Hong (Eds.), Flora of China, Vol.25. Science Press, Beijing, Missouri Botanical Garden Press, St. Louis, USA, 2009. 
3. Choudhury S, S Kr Mukherjee and H J Chowdhery. "Distribution and diversity of the genus Habenaria Willdenow (Orchidaceae) in India". In: Recent Studies in Biodiversity and Traditional Knowledge in India, Ghosh C and A P Das (Eds.), Gour Mahavidyalaya, Malda, 2011, $81-90$.

4. Chowdhery HJ. "Orchid Flora of Arunachal Pradesh". Bishen Singh Mahendra Pal Singh, Dehra Dun, India, 1998.

5. Chowdhery H J. "Orchid diversity in North-Eastern states of India". The Journal of the Orchid Society of India, 2009, 23 (1-2): 19-42.

6. Deb CR and $\mathrm{T}$ Imchen. "Orchid Diversity of Nagaland". Scichem Publishing House, Udaipur, Rajasthan, India, 2008.

7. Deb CR, NS Jamir and T Imchen. "Orchid Diversity of Nagaland". A revised status. The Journal of the Orchid Society of India, 2003, 17(1-2): 5-15.

8. Deorani SC \& HB Naithani. "Orchids of Nagaland". Oriental Enterprises, 25 A Kalidas Road, Dehra Dun, 1995.
9. Hynniewta T M, S K Kataki and Wadhwa BM. "Orchids of Nagaland". Botanical Survey of India, Calcutta, 2000.

10. King $G$ \& $R$ Pantling. "The Orchids of SikkimHimalaya". Annals of the Royal Botanical Garden, Calcutta, 1898, 8: 1 -342.

11. Kurzweil H. "The genus Habenaria (Orchidaceae) in Thailand". In: Thai Forest Bulletin (Botany), 2009, Special Issue: 7-105.

12. Pearce N \& P J Cribb. "The Orchids of Bhutan". In: Flora of Bhutan, 3(3): 1-643. Royal Botanic Garden, Edinburgh and Royal Government of Bhutan, Thimpu, 2002.

\section{Cite this article as:}

Wenyitso Kapfo and Neizo Puro. Addition of Habenaria pantlingiana Kraenzl. in the Orchid Flora of Nagaland, India. Annals of Plant Sciences 7.3 (2018) pp. 2107-2109.

do $\mathrm{http://dx.doi.org/10.21746/aps.2018.7.3.3}$

Source of support: Government of Nagaland, India.

Conflict of interest: Nil 